\title{
THE RECOGNITION OF RESOURCE USE THROUGH INDUSTRIAL DEVELOPMENT FROM A SOCIAL PERSPECTIVE ${ }^{1}$
}

\author{
Bálint Horváth \\ PhD student \\ Climate Change Economics Research Centre, Szent István University \\ E-mail: horvath@carbonmanagement.hu
}

\begin{abstract}
Rural population is vulnerable partly for its lack of self-sufficiency. This recognition considerably varies from the way rural territories functioned more than 200 years ago. The peasant societies were well known about sustaining themselves. A major trigger for the disappearance of this pattern was industrialization. This paper explicitly reviews a social perspective of industrialism and provides a novel point of view regarding its overall recognition. The present study states that there was an incremental effect of relying on machines. People have lost their sense of practical skills. Another hidden pattern of development was to utilize finite resources. The reason behind it might come from the fact that this way allows companies to distribute energy according to their own terms. As a conclusion, the paper argues that centralized (energy and industrial) production systems have increased the dependence of society - especially in case of rural population. Furthermore, it claims that the next stage of industrial revolution could enable people to return to self-sufficiency.
\end{abstract}

Keywords: industrial revolution, self-sufficiency, resource management

JEL classification: Q55, Q57

LCC code: HD2329

"The Fourth Industrial Revolution is not just about technology or business, It's about society." - Joe Kaeser,

President and Chief Executive Officer Siemens $A G$

\section{Introduction}

The present study is the launching milestone of a broad research. It was conducted within the framework of an initiative, which aims at establishing good governance through public service development. This very paper contributes to the environmental aspects of achieving secure rural life conditions. Ecological circumstances affect the welfare of rural societies in several ways (Magda, 2011). The current article would introduce a unique perspective since it does not examine the impact of environmental issues but links their roots with the problems of rural regions. Rural population is vulnerable partly for its lack of self-sufficiency (Hogan - Lockie, 2013; Szilágyi-Boldizsár, 2016). This recognition considerably varies from the way rural territories functioned more than 200 years ago. The peasant societies were well known about sustaining themselves (Simai, 2015). What has changed from then? One explanation is urbanization, which has moved many people to cities, leaving rural areas as suppliers of

\footnotetext{
${ }^{1}$ This work was created in commission of the National University of Public Service under the priority project KÖFOP-2.1.2-VEKOP-15-2016-00001 titled "Public Service Development Establishing Good Governance" and the Cooperative Partner/Institution
} 
agricultural products. A major trigger of this phenomenon was industrialization. While the previously used goods have been manufactured in small local workshops, industrialism has brought the concept of factories (Rosen, 2012). Novel technologies enabled people to enhance mass resource use in a degree that has never been seen before. On the other hand, mass products have made handcrafted goods less competitive. Therefore, former small-scale manufacturers have been forced to give up on their jobs and find new ones at factories. Obviously, these facilities did not need that much of a workforce, since they rather employed machinery than human labour.

Technological innovations did not only influence the migration of population, but the movement of markets as well. By the $20^{\text {th }}$ century, humanity has faced another controversial phenomenon, globalisation. Opening markets have opened material flows. An open material flow could be interpreted in different ways. One is related to the loss of materials during product life cycle (EMF, 2014). The other means the regional distance of material flows (de Wit et al., 2016). The currently trending concept of Circular Economy offers a new economic paradigm of closed material loops. The notion depicts a new mechanism of production systems where the material cycles would be closed. It refers to not losing any materials throughout product life cycle and also to circulate the used materials within the shortest regional circle as possible (Fogarassy et al., 2016). This paper is focused on the latter aspect. The first chapter is going to introduce extensive literature on the role of resources in human and economic history. Based on the initial findings, the analysis will propose two hypotheses in the research part. First, this study states that the theory of resource efficiency is partly a myth. It claims that in the past two centuries resource efficient technologies sometimes resulted in a more intense use of resources. The second hypothesis will be the original added value of the research. It explicitly reviews a social perspective of industrialism and provides a novel point of view regarding its overall recognition. As a conclusion, the paper argues that centralized (energy and industrial) production systems have increased the dependence of society - especially in case of rural population. Furthermore, it claims that the next stage of industrial revolution could enable people to return to self-sufficiency.

\section{Theoretical background}

\section{The importance of resources in human and economic history}

The human history can be interpreted in many ways according to several viewpoints. By certain perceptions, it could be described in terms of resources. The utilization of resources goes back a long way in time since they have always been the basis of human life. People always needed the basic natural resources as fresh air, clean water and land (Magda, 2010). Later on, with the development of communities, man has learned to extract other resources to make and employ new tools. At the initial stages of time, these communities conquered their own piece of land with the necessary resources and held possession over them. The first conflict of interest between man and man had happened when one wanted to take over a resource's possession from the other. Historians use to describe this movement with a single word: war. Even though the participants always tend to associate their involvement with alternate purposes - as liberty, religion etc. - the main motive behind every war in human history has been about the possession of resources (Gedicks, 1993). The most emblematic example of reckless resource management and overexploitation of natural values is the case of the Easter Island. The population of the island has simply grown over its available resources and then started to fight each other for the remaining pieces (Brander - Taylor, 1998). Current historic findings might doubt this theory (Jarman et al., 2017) however the pure assumption describes the attitude of humanity very well. 
The importance of resources applies not only to the human history but to a more specific area, the economics. The original concept of economics itself describes a field of study which is concerned with the way society manages its scarce resources (Mankiw, 2012). The word 'resource' is a widely used term in the world of economics and in general language as well. However, the true definition of resources often gives a tough time to people. This controversial role may come from their caprice existence. According to Erich Walter Zimmermann (18881961) a resource cannot be defined as an exact subject. Throughout history, humanity has employed many different things to perform production activities. It is enough to look at the names of several historic ages as they have been labelled in accordance with the most utilized actual resource (e. g. stone or bronze age). Therefore, the word resource rather refers to a certain function which would be appointed to things by humanity in each time. It could also happen that a subject considered as a resource today may not remain that tomorrow. So, the same Zimmermann - who is still held as one of the most significant resource economists - stated that "resources are not, they become" (Zimmerman, 1951; Gregori, 1987). Besides the interpretation of the term, the classification proves to be another ground for scientific debate. Classical economics serves with a rather simple categorization with mentioning only labour, land and capital. The first group consists of all human efforts manifested in the production of goods and is compensated by wage. The second type means both the place of production and all the natural resources used as raw material inputs. Eventually, capital is an already produced subject which could be any employed infrastructure as machinery or buildings etc. (Samuelson - Nordhaus, 2009). Ever since the existence of this traditional grouping, many other theories had come up. The novel redistributions differentiate the same classes of resources (labour, land and capital) according to varying criteria. They distinguish assets according to their durability, availability, tangibility and origins. Although the new perspectives have altered through time, the subjects remained the same.

\section{The hidden role of resources in economic growth}

The presented function of resources regarding human and economic history requires an alternate point of view to be discovered. Most of the concepts do not focus on resources because they are either considered given or being neglected besides other key aspects. However, it is obvious that they were truly a reason for the rise and fall of many societies. One of the main attributes of modern societies is their dependence on their economies. Since resources play a key role in the operation of economies, it is not surprising to acknowledge their significance in social movements. Still, economic theories tend to focus on other characteristics without highlighting the resources. One of the most well-known concepts on economic development might be the cycle-based model of Nikolai Kondratieff (1892-1938). His theory has also been referred as Kondratieff wave (Figure 1.). In his book "The Major Economic Cycles" he reviewed the evolution of modern economics and observed long-term tendencies lasting for over 50 years (Tanning et al., 2013).

These time intervals have been called "long cycles" and started a long debate between economists. By that time, the scientific community was only aware of Joseph Kitchin's (18611932) business cycle (3-5 years) and Clément Juglar's (1819-1905) fixed investment cycle (711 years) which were short-term economic theories. Simon Kuznets (1901-1985) came up only five years after Kondratieff with his Kuznets swing (15-25 years) as a medium-range economic period. Therefore, Kondratieff's theory about observing exact 50 years long economic lifespans have been regarded with controversial feelings. Some experts denied the theory of long cycles and argued that even in case of their existence the length of these intervals could vary due to innovation and technological development (Korotayev - Tsirel, 2010). Other researchers admitted the appearance of long cycles and even traced back economic history to identify cycles 
before the $19^{\text {th }}$ century. A study from the mid-1990's highlighted 18 Kondratieff waves back to the year of 930 (Modelski - Thompson, 1995). Joseph Schumpeter (1883-1950) also stood for the idea and suggested to combine the certain cycles into one macroeconomic growth model. In his opinion, long cycles truly existed, and they were caused by innovation. He thought that every economic era has its own prosper period but after a certain point, there is no room for further development based on the current technology and knowledge. Therefore, a recession and a final depression is expected to come which must be followed by an innovative breakthrough. In his mind, entrepreneurs were the main drivers of novel economic triumphs reached by disrupting existing industries. Obviously, it meant the downfall of former systems that also influenced their businesses and workers. It might sound cruel, but it was the necessary damage in order to flourish again. This is the reason he called this phenomenon "Creative destruction" (Schumpeter, 1976; Reinert - Reinert, 2006). Even though this research approves this concept, the loss of workplaces through technological innovation will be further reviewed in this article.

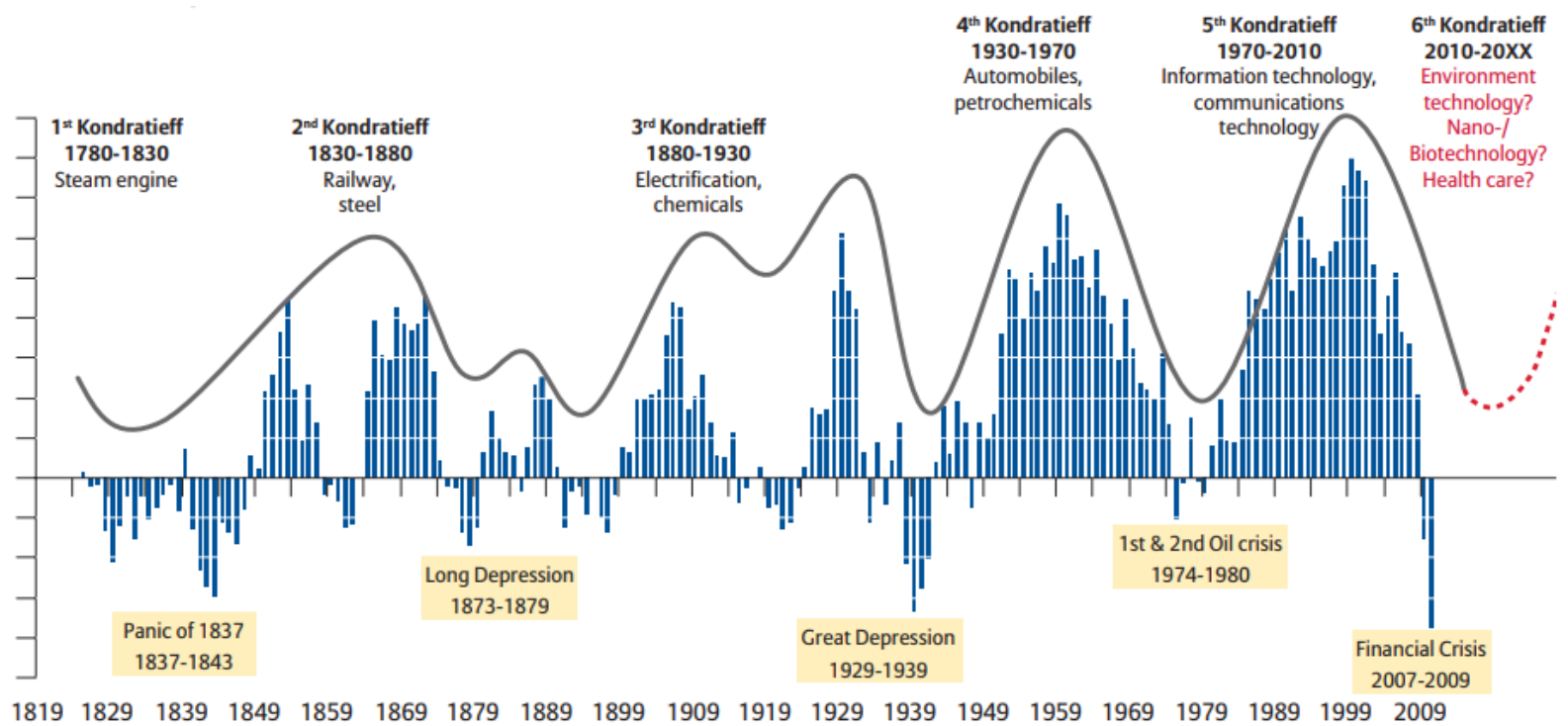

Source: Allianz, 2010

Figure 1. The Kondratieff Waves

There is another statement of Schumpeter's growth theory that must be cleared first. It is related to the use of resources throughout the cycles. When we take another look at Figure 1, one shall find that not all the economic crises have been linked directly to resources - except for the OPEC oil crises. However, all the influential technologies leading to prosperity utilized new resources. Schumpeter stated that innovation frees up resources or finds uses that are more productive for them (Schumpeter, 1961). By this thought, he also admits that an era might reach its economic peak, but the current technology or knowledge is not always the reason for depression. Another important aspect could be the lack of determinative resources to maintain growth. Whenever this situation occurs, people must find either a more efficient way to utilize their current resources or simply find new ones. If one of these options could be realized, policymakers feel comfortable and expect the economy to grow again. At least that would be the case in terms of traditional economic thinking. Welfare and ecological economists think a bit different though. The further aim of the study will be to examine both cases: the more efficient use of former resources and the utilization of new ones. The main research question is to figure out whether they truly contribute to social and environmental benefits or just misleading decision makers. 


\section{Research material and methodology}

The focus of this research will be on a literature review from welfare and ecological economics. Based on the analysis conducted in the followings, the previously presented scientific theories will be overviewed and criticized. The controversial theory of enhanced resource efficiency will be examined, and the discovery of new resource uses would be critically reconsidered. The present research assumes that improved efficiency might lead to the eventual overexploitation (or waste) of resources and novel technologies strengthen the former system in long term.

\section{The deceptive concept of enhanced resource efficiency}

One of the most important role of science - especially in case of social and economic sciences - is to contribute to decision-making. This duty can be controversial, since decision-making would require choosing from two (or more) extremes. However, the solution mostly lies in the way middle of certain options. U. S. president Harry S. Truman once said that "Give me a onehanded economist! All my economists say: on the one hand on the other". He clearly meant that economists usually do not tend to take bold positions, because they like to consider all potential factors. As the world is not always black and white but rather opaque, these scientists barely advise decision makers to commit themselves to extremes. This careful consideration was the launching milestone of ecological economics as well. In 1865 economist, William Stanley Jevons (1835-1882) published his fundamental - although poorly recognized - book, "The Coal Question". While many British factories gladly employed the novel, more resourceefficient Watt steam engine, Jevons had looked into its real impacts. Soon he realized that relying on the new technology might cut production costs, but it makes coal a cheaper input as well. Producers started to utilize considerable amount of coal due to its cost-efficiency. The new technology was environmental-efficient, but the mass coal burning resulted in more greenhouse gas emissions than before (Jevons, 1865). This controversy has become known as Jevons paradox (Sorrell, 2009) and still marks the birth of environmental economics. Unfortunately, it has been neglected for a long time. Its second appearance urged nearing the end of another Kondratieff cycle, by the occasion of the OPEC oil crises.

Since oil prices have become considerably high, it has suddenly turned into a scarce resource. The reason was not the lack of its presence, but the act from its suppliers to influence western economies. Even though it was an artificial intervention, it provided the perfect case study for the behavioural amendments of economic stakeholders. As people have done it many times before, now they started to look for resource alternatives and efficient usage of oil. For the sake of the latter, companies have come up with new automobiles that consumed less fuel. At this point one shall assume that this phenomenon has decreased oil consumption and carbon dioxide emissions. Nevertheless, the case was once again different, and many aspects contributed to it. First, the customer attitude regarding cars varies from other products. Most people do not buy them because they could not afford its maintenance costs. The price of purchase is not always the reason. So fuel-efficient cars would inspire many people to buy them since their usage is cheaper. Another problem is the overall recognition of resources among society. The cheaper they are, the more they will be used. Researches that examined the social impact of overhead cost reduction concluded that the society does not save as much money as it was expected (Sorrell, 2007). The reason was the increased use of household energy due to its easier accessibility. Situation is the same with cars. When people can access to oil cheaper, they tend to drive more instead of reducing their fuel expenses. The case with this resource crisis has become worse. Since it was artificial and there was not real shortage of oil, the prices dropped later. Therefore, the same price as before has been turned even cheaper (Khazzoom, 1989; Saunders, 2008). This relation has been discovered in the 1980's by economists Daniel 
Khazzom (1932-) and Leonard Brookes (1919-2016) who extended Jevons' findings to all applicable resources.

Nowadays, this phenomenon is referred as the "Rebound effect" and stands for the unintended consequences of resource-efficiency developments, which lead to overexploitation of resources. The sad part of this case is the way it has remained neglected. Despite energy economists still discover practical appearances of energy rebound due to more efficient technologies, these appliances are yet considered "eco". As a conclusion to this sub-chapter and the related hypothesis, it is to state that novel technologies intend to result in the opposite of their initial aim. Decision makers must consider this phenomenon, since resource-efficient technologies are still involved in environmental strategies (Brockway et al., 2017). Joseph Schumpeter's theory still stands in terms of economic aspects. Even energy economists admit that energy rebound stimulates a rather higher economic growth then it is expected by the innovation itself. The reason is that producers and consumers spend the money from energy savings on increased production and consumption activities (Saunders, 1992). The further question is that whether the economic value of the generated environmental externalities surpass the economic benefits or not (Horvath - Magda, 2017). Schumpeter was also right about innovations triggering a creative destruction and creating new regimes. It was not even the aim of this study to examine that statement. The real ground for debate is the doubt regarding these regime changes. Schumpeter had argued that systems change, and one shall follow the other. The example of the past 250 years - the period of Kondratieff cycles - can be interpreted in another way. It is obvious to see that economies rely on certain production systems, which are based on resources. Once economies run out of their resources, they start to look for others to maintain growth. Nevertheless, the question is why would they always end up relying on finite resources? The next part of the research will focus on providing answers for that.

\section{Industrial (R)evolution - Industry 4.0: A New Hope}

The second hypothesis of this research is a broad aspect, which requires a multidimensional perspective. The aim of this study is not to elaborate on the entire system. It is only to introduce an argument regarding modern societies' self-destructing behaviour in the past 200 years. It is the time interval when humanity's lifestyle has started to deviate from the natural order and its ecological footprint has increased enormously. This process has been described in many researches before, therefore it does not make the focus of the current one. It is rather the controversy how this so-called "development" has always been fuelled by fossil resources. To find reasons for the recent circumstances, one must start to look for answers in the previous times. Thus, the question is: how was humanity 200-250 years before? As it was described in the historical analysis, mankind has had its mentality of fighting each other over the possession of resources. When it discovered new pieces of land, it exploited their resources through the destruction of the local native societies. In a civilized manner, this phenomenon is called "colonization". When the newly discovered territories have been distributed among the certain empires, the old method of fighting wars continued. However, the colonists have made some observations. Not all conquers have required violence. In some cases, the most dangerous weapon of humanity was simply enough. It was civilization itself. Besides its many negative attributes, civilized lifestyle has had its benefits for the people living in nature. The pursuit of status symbols (which is a pillar of the current consumer society), the preference of private property and (easily accessible) produced goods over common benefits and self-sufficiency can be seductive. The wind of civilization had put a spell on these communities (Korten, 1995). Later, they have generated a demand for products they have never known before. For the acquisition of these commodities they needed their colonizers, meaning they had lost their independence. Not in a legal, but in a moral sense. According to certain researches (Simai, 
2015), the greatest loss of spreading the western society's culture is not finding a current culture without its trademark.

After the historic detour on the extension of civilization, the driving question needs to be rephrased: how were civilized societies 200-250 years before? They might not have been so much aligned with nature, but the people of that time were also self-sufficient. They lived mostly in peasant societies where the dominant agricultural activity has been accompanied by manufacture and commerce. Individuals have not always been entirely self-sufficient, but communities have. Local agricultural producers and manufacturers consumed each other's products. Then occurred the phenomenon called the first industrial revolution. It has started with the mechanization of the textile industry in the second half of the $18^{\text {th }}$ century and continuously spread across Western Europe (Rosen, 2012). Industrialization has been initially considered convenient. It was not the first time for humanity inventing tools to produce goods faster. However, the mass utilization has eventually brought the disadvantages of industrial production. Human labour has been more and more replaced by machinery and the unemployed have started to protest. That was obviously not like the current consumer society where the economic growth is maintained by intemperate consumption. Nevertheless, economists highlighted the contradiction of employing machines to increase production and still expecting unemployed people to consume. This observation was one of the main arguments in Karl Marx' 1876 book, "The Capital" (Jones, 2017). There is a more disadvantageous effect of it though. As falling out of industrial sectors, people needed to look not only for other, but also for entirely different type of jobs. Fortunately, a demand has started to come up for other goods, which were not commodities but services. The rise of service sector and commerce have meant in some way to be the saviour of humanity by providing workplaces.

However, there was an incremental effect of relying on machines. People have lost their sense of practical skills. This phenomenon prevented them from preparing or repairing their own tools. In a certain way, industrial revolution can be interpreted as telling someone: "Do not do it, I will do it for you and let you pay for it." Obviously, there is a lot more to industrialization than this single aspect, but it must be highlighted to understand the argumentation of this research. The current study stated that there might be continuously changing regimes but the system at some point remains the same. In case of the Kondratieff waves, it was clear to see that despite the alternation of certain systems, one particular aspect stayed unchanged. It was the utilization of finite resources. The train of thoughts presented in this research leads us to two questions. First, why would all the economic paradigms harness fossil fuels? Second, why does industrialism aim at keeping people from self-sufficiency? The same answer applies to both questions: to make societies dependent. As long as systems are based on limited resources, which are owned by private companies, there will always be a price to pay for them. This is the reason why the concept of "energy democracy" and "energy independency" has become popular lately. It means communities breaking away from centralized fossil energy providers and setting up their own renewable energy cooperatives. It enables them to produce energy for themselves and be self-sufficient on this field (Rae - Bradley, 2012). Regarding industrialism, the purpose is the same, but the mechanism is different.

By looking at the flow of industrial revolutions (Figure 2.), one shall observe that the milestones are aligned with the previously presented Kondratieff waves. The first two waves have occurred during the time of the first revolution and the third and fourth waves at the second industrial period. The fifth long cycle is mostly covered by the third industrial step and researchers are still in a debate regarding the times to come. Many argue that the global economy has already stepped into its sixth Kondratieff period and has reached the fourth industrial revolution (Sauberer et al., 2017). 


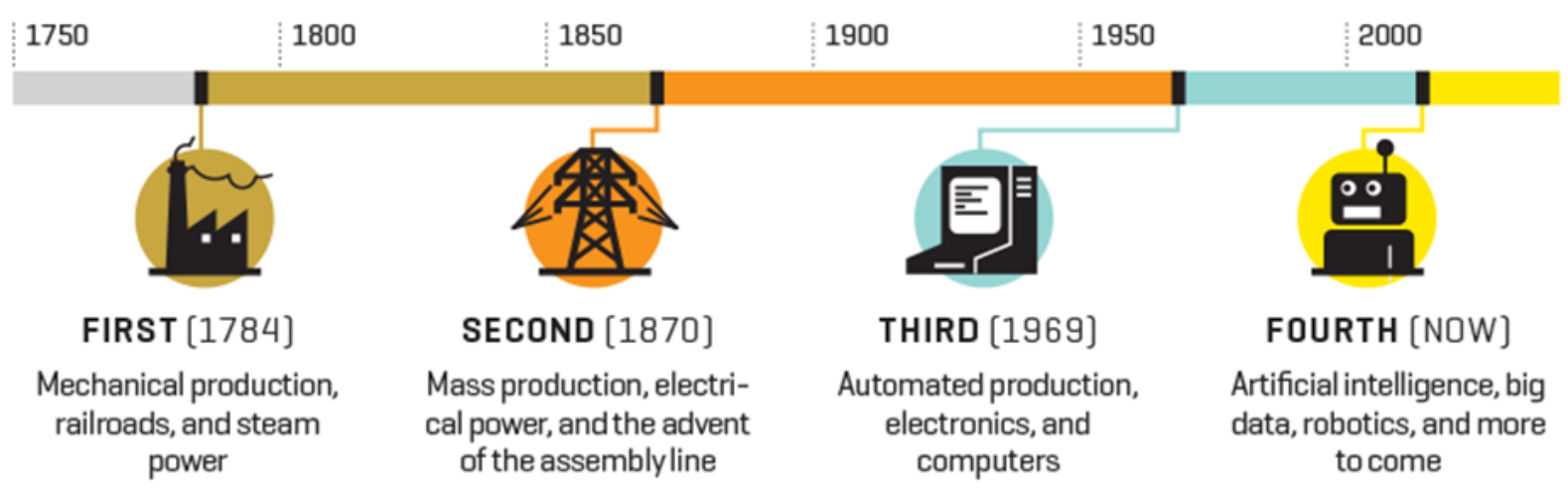

Figure 2. The four stages of industrial revolutions

Source: Demandbase, 2017

Industry 4.0 - as it is mostly referred - promises to be the age of artificial intelligence where services will be provided by novel digital technologies. This pattern would eliminate the need for intermediary actors, in other words: the "middleman". It is a well-known term of modern economies where an agent interferes in the business of two parties. This intermediate action results in additional costs. As modern technologies (e. g. 3D printing, digital services) enable people to free themselves from that intermediary, these costs will also decrease (Rifkin, 2014). Eventually, the next industrial revolution could be a tool to provide societies with selfsufficiency.

\section{Results and discussion}

The present study engaged in proving the essential role of resources throughout human and economic history. The analysis showed that resources have been among the main motives behind significant social and economic paradigm shifts. Their utilization and their presence have defined the behaviour and fate of societies. Although, there might have been immoral effects of pursuing their possession, they mostly influenced societies and economies. Then 250 years ago, something has changed. Humanity developed tools for the mass exploitation of finite resources, which resulted in major reduction regarding their quantity. This process increased the ecological footprint of humans enormously. Meanwhile, the concept of modern economy was born, and its growth needed to be maintained. In order to enhance productivity, people have come up with more resource-efficient technologies. Later, the concept of resource efficiency has been proven to be misleading. These novelties have only made the use of resources cheaper and attracted more people to their utilization. This phenomenon has eventually lead to their faster depletion. The presented literature review proved the first hypothesis to be right. Efficient utilization causes mass exploitation. However, this is barely a novel finding, since its very first observation has occurred in the second half of $19^{\text {th }}$ century. This paper only emphasizes it because current policymakers seem to be still ignorant regarding this matter.

The second statement of the research is a rather exciting one. By the examination of both long Kondratieff waves and industrialism, the importance of resources was also featured. The findings recognized Schumpeter's opinion on innovations as being the driving force of economic regime changes. Many notable inventions aimed at utilizing current resources more efficiently or harnessing new ones. Therefore, they have created a room for further development. This study argues that referring to the economic regimes changes - marked by long waves and industrial revolutions - could be deceptive as well. Obviously, this is a quite broad topic and the analysis only highlights a significant pattern of it. It is clear to see that even 
if new economic systems keep replacing each other, one aspect remains the same. They continuously rely on finite resources. This manner allows a few companies to centrally take control over their utilization and put themselves in a monopoly. The same goes to industrial production. The first industrial revolution has excluded human labour from production processes and the following ones further decreased the need of creative workforce. As an incremental effect, local production has been substituted by monopolistic centralized systems. It can be concluded that the energy and industrial systems of the past two centuries have been established to capitalize on people's dependence. Furthermore, there are already initiatives to turn back this course. Local communities achieve energy independence by setting up renewable energy cooperatives and our industry is about to change as well. Industrialism has been one of the reasons many people lost their functional independence. Its new stage, the fourth revolution could be the one to redeem this action and equip people to be self-sufficient again.

\section{Acknowledgement}

This work was created in commission of the National University of Public Service under the priority project KÖFOP-2.1.2-VEKOP-15-2016-00001 titled "Public Service Development Establishing Good Governance" and the Cooperative Partner/Institution

\section{References}

1. Allianz. (2010): The sixth Kondratieff - long waves of prosperity. Allianz, 2010 January, Analysis \& Trends report, 28 p.

2. Brander, J. A. - Taylor M. S. (1998): The Simple Economics of Easter Island: A Ricardo-Malthus Model of Renewable Resource Use. The American Economic Review, 88 (1), 119-138.

3. Brockway, P. E. - Saunders, H. - Heun, M. K. - Foxon, T. J. - Steinberger, J. K. Barrett, J. R. - Sorrell, S. (2017): Energy rebound as a potential threat to a low-carbon future:Findings from a new exergy-based national-level rebound approach. Energies, 10 (1), 51. http://dx.doi.org/10.3390/en10010051

4. De Gregori, T. R. (1987): Resources Are Not; They Become: An Institutional Theory. Journal of Economic Issues, $21 \quad$ (3), 1241-1263. http://dx.doi.org/10.1080/00213624.1987.11504702

5. de Wit M. - Bardout M. - Ramkumar S. - Kubbinga B. (2016): The Circular Dairy Economy - Exploring the business case for a farmer led, 'netpositive' circular dairy sector. Publisher: Circle Economy / Friesland Campina in Holland, 20 p.

6. Demandbase. (2017): 4 Key Themes We Saw at Dreamforce 2017. Online: https://www.demandbase.com/b2b-marketing-blog/4-key-themes-saw-dreamforce$\underline{2017 /}$

7. Ellen MacArthur Foundation. (2014): Towards the Circular Economy: Accelerating the scale-up across global supply chains. Ellen MacArthur Foundation Publisher, 64 p.

8. Fogarassy, Cs. - Orosz, Sz. - Ozsvári, L. (2016): Evaluating system development options in circular economies for the milk sector-Development options for production systems in the Netherlands and Hungary. Hungarian Agricultural Engineering, 30, 6274. http://dx.doi.org/10.17676/HAE.2016.30.62

9. Gedicks A. (1993): The New Resource Wars: Native and Environmental Struggles Against Multinational Corporations. South End Press, 270 p. ISBN: 978-0896084629

10. Hogan, A. - Lockie S. (2013): The coupling of rural communities with their economic base: agriculture, localism and the discourse of self-sufficiency. Policy Studies, 34 (4), 441-454 p. http://dx.doi.org/10.1080/01442872.2013.822702 
11. Horvath, B. - Magda R. (2017): Possible bottlenecks in the strategic management of environmentally engaged companies - Transition to the world of circular businesses. In: 12th International Conference on Strategic Management and its Support by Information Systems, 11-20 p.

12. Jarman, C. L. - Larsen, T. - Hunt, T. - Lipo, C. - Solsvik, R. - Wallsgrove, N. Ka'apu-Lyons, C. - Close, H. G. - Popp, B. N. (2017): Diet of the prehistoric population of Rapa Nui (Easter Island, Chile) shows environmental adaptation and resilience. American Journal of Physical Anthropology, 164, (2), 343-361. http://dx.doi.org/10.1002/ajpa.23273

13. Jevons W. S. (1865): The Coal Question. London, Macmillan \& Co, 213 p.

14. Jones, G. S. (2017): In retrospect: Das Kapital. Nature, 547, 401-402. http://dx.doi.org/10.1038/547401a

15. Khazzoom, J. D. (1989): Energy Savings from More Efficient Appliances: A Rejoinder. The Energy Journal, 10 (1), 157-166. http://dx.doi.org/10.5547/ISSN01956574-EJ-Vol10-No1-14

16. Korotayev, A. V. - Tsirel, S. V. (2010): A Spectral Analysis of World GDP Dynamics: Kondratieff Waves, Kuznets Swings, Juglar and Kitchin Cycles in Global Economic Development, and the 2008-2009 Economic Crisis. Structure and Dynamics 4 (1), 357.

17. Korten D. C. (1995): When Corporations Rule the World. Berrett-Koehler Publishers, $386 \mathrm{p}$.

18. Magda R. (2010): A vidékgazdaság fejlödésének természeti alapjai (in Eng: The natural base of rural economy development). in: Magda R. - Marselek S. (eds.): Vidékgazdaságtan I: A vidékfejlesztés gazdasági folyamatai (in Eng: Rural Economy I: The economic processes of rural development). Szaktudás Publishing House, 41-95 p.

19. Magda, R. (2011): A zöldgazdaság és a foglalkoztatás (in Eng: The Green Economy and Employment). Európai Tükör: Az integrációs stratégiai munkacsoport kéthavonta megjelenő folyóirata (1996-2011), 2011 (4), 85-96.

20. Mankiw N. G. (2012): Principles of Economics (6 ${ }^{\text {th }}$ edition). Boston, South-Western College Publishing, 576 p., ISBN: 978-1285032184

21. Modelski G. - Thompson W. R. (1995): Leading Sectors and World Powers: The Coevolution of Global Economics and Politics. University of South Carolina, $263 \mathrm{p}$. ISBN: 978-1570030543

22. Rae, C. - Bradley, F. (2012) Energy autonomy in sustainable communities - a review of key issues. Renewable and Sustainable Energy Reviews, 16 (9), 6497-6506, http://dx.doi.org/10.1016/j.rser.2012.08.002

23. Reinert H. - Reinert E. S. (2006): Creative Destruction in Economics: Nietzsche, Sombart, Schumpeter. In: Friedrich Nietzsche 1844-1900: Economy and Society, Chapter 4, Springer Publisher, 55-85 p. http://dx.doi.org/10.1007/978-0-387-3298024

24. Rifkin J. (2014): Zero Marginal Cost Society. Palgrave MacMillan Trade, 368 p. ISBN: 978-1137280114

25. Rosen W. (2012): The Most Powerful Idea in the World: A Story of Steam, Industry and Invention. University of Chicago Press, 149 p. ISBN: 978-0-226-72634-2

26. Samuelson P. A. - Nordhaus W. D. (2009): Economics $\left(19^{\text {th }}\right.$ edition). McGraw-Hill Education, 744 p. ISBN: 978-0073511290

27. Sauberer, G. - Riel A. - Messnarz R. (2017): Diversity and PERMA-nent Positive Leadership to Benefit from Industry 4.0 and Kondratieff 6.0. In: EuroSPO 2017: 
Systems, Software and Services Process Improvement, 642-652 p. http://dx.doi.org/10.1007/978-3-319-64218-5 53

28. Saunders, H. D. (1992): The Khazzoom-Brookes postulate and neoclassical growth. The Energy Journal, 13 (4), 131-148. http://dx.doi.org/10.5547/ISSN0195-6574-EJVol13-No4-7

29. Saunders, H. D. (2008): Fuel conserving (and using) production functions. Energy Economics, 30 (5), 2184-2235. http://dx.doi.org/10.1016/j.eneco.2007.11.006

30. Schumpeter J. A. (1961): The theory of economic development: an inquiry into profits, capital, credit, interest, and the business cycle. New York, Oxford University Press, $255 \mathrm{p}$.

31. Schumpeter J. A. (1976): Capitalism, Socialism and Democracy ( $5^{\text {th }}$ edition). George Allen \& Unwin, $437 \mathrm{p}$.

32. Simai M. (2015): A harmadik évezred nyitánya - A zöld fejlődés esélyei és a globális kockázatok. Budapest, Corvina Kiadó, 374 p. ISBN: 978-963-13-6385-2

33. Sorrell, S. (2007): The rebound effect: An assessment of the evidence for economywide energy savings from improved energy efficiency. London, Energy Research Centre, $108 \mathrm{p}$.

34. Sorrell, S. (2009): 'Jevons' Paradox revisited: The evidence for backfire from improved energy efficiency'. Energy Policy, 37 (4), 1456-1469. http://dx.doi.org/10.1016/j.enpol.2008.12.003

35. Szilágyi T., Boldizsár G.: (2016) A biztonságos vidék, mint az állam létfeltétele $P R O$ SCIENTIA RURALIS 1:(4) pp. 24-34.

36. Tanning, T. - Saat, M. - Tanning, L. (2013): Kondratieff wave: overview of world economic cycles. Global Business and Economics Research Journal, 2 (2), 1-11.

37. Zimmerman E. W. (1951): World Resources and Industries - A Functional Appraisal of The Availability of Agricultural and Industrial Materials. New York, Harper and Brothers, 823 p. 